Disclosure of Interests: Michal Rudnik: None declared, Amela Hukara: None declared, Przemyslaw Blyszczuk: None declared, Oliver Distler Speakers bureau: Actelion, Bayer, Boehringer Ingelheim, Medscape, Novartis, Roche, Menarini, Mepha, MSD, iQone, Novartis, Pfizer, Consultant of: Abbvie, Actelion, Acceleron Pharma, Amgen, AnaMar, Arxx Therapeutics, Bayer, Baecon Discovery, Blade Therapeutics, Boehringer, CSL Behring, ChemomAb, Corpuspharma, Curzion Pharmaceuticals, Ergonex, Galapagos NV, GSK, Glenmark Pharmaceuticals, Inventiva, Italfarmaco, iQvia, Kymera, Medac, Medscape, Mitsubishi Tanabe Pharma, MSD, Roche, Sanofi, UCB, Lilly, Target BioScience, Pfizer, Grant/ research support from: Actelion, Bayer, Boehringer Ingelheim, Kymera Therapeutics, Mitsubishi Tanabe, Gabriela Kania: None declared DOI: 10.1136/annrheumdis-2021-eular.2869

\section{POS0429 \\ INTERLEUKIN-4 ACTIVATES EOSINOPHILS AND CCR3-POSITIVE T HELPER CELLS MIGRATION TO FASCIA AND PROMOTES FIBROSIS IN EOSINOPHILIC} FASCIITIS

M. Hosonuma ${ }^{1,2,3,4}$, T. Isozaki ${ }^{2}$, H. Furuya ${ }^{2}$, Y. Yamazaki ${ }^{5}$, Y. Ikari ${ }^{2}$, S. Nishimi ${ }^{2}$ A. Maeoka ${ }^{2}$, S. Ishii ${ }^{2}$, T. Tokunaga ${ }^{2}$, K. Wakabayashi ${ }^{2}$, N. Konishi ${ }^{2}$, S. Fukuse ${ }^{2}$, K. Ishikawa ${ }^{6}$, N. Sakai ${ }^{7}$, K. Inagaki ${ }^{6}$, T. Kasama ${ }^{2}{ }^{1}$ Clinical Research Institute for Clinical Pharmacology \& Therapeutics, Showa University, Department of Clinical Immuno Oncology, Tokyo, Japan; ${ }^{2}$ Showa University, Division of Rheumatology, Department of Medicine, Tokyo, Japan; ${ }^{3}$ Showa University, Division of Medical Oncology, Department of Medicine, Tokyo, Japan; ${ }^{4}$ Showa University, Department of Pharmacology, School of Medicine, Tokyo, Japan; ${ }^{5}$ Showa University School of Pharmacy, Division of Toxicology, Department of Pharmacology, Toxicology and Therapeutics, Tokyo, Japan; ${ }^{6}$ Showa University School of Medicine, Department of Orthopaedic Surgery, Tokyo, Japan; ${ }^{7}$ Showa University School of Dentistry, Department of Pharmacology, Tokyo, Japan

Background: Eosinophilic fasciitis (EF) is a rare disease that causes inflammation and fibrosis mainly in the fascia of the extremities with eosinophilia. It has been reported that the hypertrophied fascia in EF shows inflammatory cell infiltration by the lymphocytes and eosinophils and increased expression of fibrosis-related cytokines genes in fibroblast [1]. However, its pathophysiology in the fascia remains unresolved.

Objectives: Therefore, we focused on fascial fibroblasts and aimed to determine the role of interleukin-4 (IL-4) in eosinophil and helper T cell infiltration and fibrosis in fascial fibroblast in EF.

Methods: Fascial fibroblasts were obtained from fascia biopsy of a patient with $E F$, and were stimulated with pre- and post-treatment serum of a patient with EF and healthy control, followed by microarray to analyze gene expression. Fascial fibroblasts were stimulated with IL-4 $10 \mathrm{ng} / \mathrm{mL}$, and gene expression of IL-4 receptor and CCR3 ligands, CCL7 and CCL11 were measured by qPCR. Transforming growth factor (TGF) $-\beta$ and periostin in the pre- and post-treatment serum of a patient with EF and conditioned medium of fascial fibroblasts stimulated with IL- 4 were measured by ELISA. To examine the role of IL- 4 in proliferation, we performed in proliferation assays using fascial fibroblasts treated with IL-4. CCR3-positive T cells in the fascial tissue of EF, dermatomyositis, and polymyositis patients were evaluated by immunostaining.

Results: By microarray analysis, CCL7 and CCL11 expression of fascial fibroblasts stimulated with pre-treatment EF serum was higher than that in post-treatment EF serum and control serum. CCL7 and CCL11 mRNA in IL-4 stimulated facial fibroblasts were increased by 5.1 -fold and 7.3 -fold, respectively. TGF- $\beta$ and periostin in IL-4 stimulated facial fibroblast conditioned medium were also increased. In addition, TGF- $\beta$ and periostin in EF serum were gradually decreased by treatment for 4 and 10 weeks, compared to before treatment. Finally, fascial fibroblast proliferation was significantly increased by stimulation with IL-4. Furthermore, infiltration of CCR3-positive T cells was specific to the fascial tissue of EF. Conclusion: In EF, IL-4 enhances the production of CCR3 ligands, TGF- $\boldsymbol{\beta}$, and periostin from fascial fibroblasts. As a result, it promotes the migration of eosinophils and CCR3-positive $T$ helper cells to the fascia and fibrosis. These results suggest that inhibition of IL-4 pathway could be a novel strategy for eosinophilic fasciitis.

REFERENCES:

[1] Igarashi A, Nashiro K, Kikuchi K, et al. Connective tissue growth factor gene expression in tissue sections from localized scleroderma, keloid, and other fibrotic skin disorders. J Invest Dermatol. 1996 Apr;106(4):729-33.

Disclosure of Interests: None declared

DOI: 10.1136/annrheumdis-2021-eular.3542

\section{POS0430 \\ EXPRESSION AND CLINICAL SIGNIFICANCE OF AUTOPHAGY-RELATED GENES IN PERIPHERAL BLOOD MONONUCLEAR CELLS OF SYSTEMIC SCLEROSIS}

Y. F. Qing ${ }^{1}$, J. Zheng ${ }^{1}$, S. B. Wang ${ }^{1}$, F. Dai ${ }^{1}$, Y. Jiang ${ }^{1}$, Y. X. He ${ }^{1}$, Q. B. Zhang ${ }^{2}$. ${ }^{1}$ Institute of Rheumatology and Immunology, Department of Rheumatology and Immunology, Nanchong, China; ${ }^{2}$ Institute of Rheumatology and Immunology,
Department of Geriatrics, Affiliated Hospital of North Sichuan Medical College, Nanchong, China

Background: Growing evidences have demonstrated that autophagy is a pow erful regulators in the pathogenesis of fibrosis and autoimmune diseases. Autophagy abnormalities in SSc involve abnormal autophagy-related protein and autophagy-related gene polymorphism ${ }^{[1-2]}$, however there is a few reports on the expression and clinical significance of autophagy-related genes.

Objectives: To investigate the expression and clinical significance of autophagy-related genes LC-3 mRNA, Becline-1 mRNA, Agt-3 mRNA, Agt-5 mRNA, Agt-12 mRNA and Agt-16L1 mRNA in peripheral blood mononuclear cells (PBMC) of systemic sclerosis (SSc).

Methods: 51 cases of SSc and 60 cases of normal control were received from the Affiliated Hospital of North Sichuan Medical College, and autophagy-related genes were detected by RT-PCR. SPSS19.0 statistical software was used to compare the expression of autophagy-related genes between groups and analyze the relationship between autophagy-related genes and clinical data, $\mathrm{P}<0.05$ was considered statistically significant

Results: LC-3, Becline-1, and Agt-3 were highly expressed in SSc compared with normal control [LC-3: $0.78(0.60) \times 10^{-3}$ vs. $0.52(0.54) \times 10^{-3}$; Beclin-1: $6.68(3.56) \times 10^{-3}$ vs. $5.22(3.54) \times 10^{-3}$; Agt-3: $17.58(12.33) \times 10^{-3}$ vs. $11.00(4.56) \times 10^{-}$ $\left.{ }^{3}, \mathrm{P}<0.05\right]$, however Agt-5, Agt-12 and Agt-16L1 of autophagy-related genes were not statistically significant [AGT-5: $6.67(3.58) \times 10^{-3}$ vs. $6.67(2.64) \times 10^{-3}$; AGT-12: $8.64(5.56) \times 10^{-3}$ vs. $8.57(4.66) \times 10^{-3}$; Agt-16L1: $2.69(2.19) \times 10^{-3}$ vs. $2.52(2.26) \times 10$ ${ }^{3}$ ] (Figure 1). Beclin-1 and Agt-5 high expressed in SSc with the positive of anti-SSA/Ro antibody. LC-3 was positively correlated with Age $(r=0.662)$ and $\mathrm{ESR}(\mathrm{r}=0.355)$ (all $\mathrm{P}<0.05)$.

Conclusion: Autophagy-related genes were increased in PBMC of SSc, and were correlated with Age, ESR and autoantibody, suggested that autophagy is a key feature in the pathogenesis of systemic sclerosis.
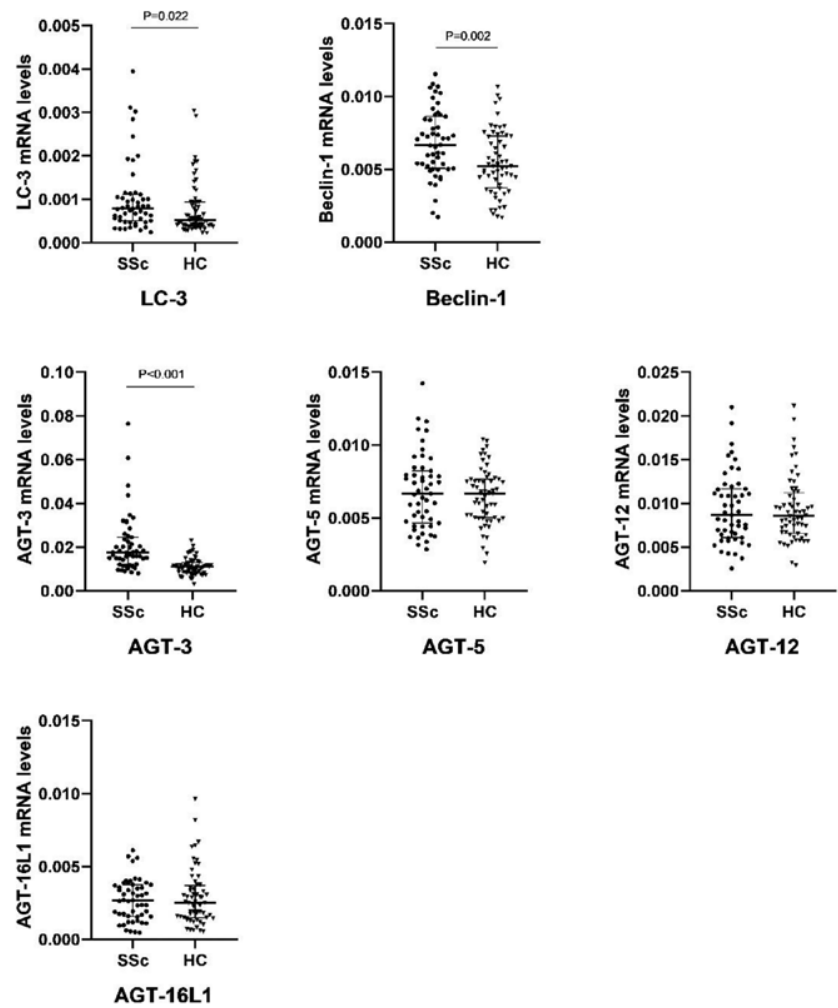

Figure 1. The relative expression of autophagy-related genes

\section{REFERENCES:}

[1] LIU C, ZHOU X, LU J, et al. Autophagy mediates 2-methoxyestradiol-inhibited scleroderma collagen synthesis and endothelial-to-mesenchymal transition induced by hypoxia[J]. Rheumatology, 2019;58(11): 1966-1975.

[2] Mayes M D, Bossini-Castillo L, Gorlova O, et al. Immunochip Analysis Identifies Multiple Susceptibility Loci for Systemic Sclerosis[J]. The American Journal of Human Genetics, 2014,94(1):47-61.DOI:10.1016/j.ajhg.2013.12.002.

Disclosure of Interests: None declared

DOI: 10.1136/annrheumdis-2021-eular.3562 